\title{
KONSEKUENSI PENERAPAN MIX PROMOSI TERHADAP KINERJA PEMASARAN BISNIS MIKRO KECIL DAN MENENGAH DI KABUPATEN KAMPAR, PROVINSI RIAU
}

\section{THE CONSEQUENCE OF MIX PROMOTION IMPLEMENTATION ON MARKETING PERFORMANCE OF SMALL AND MEDIUM MICRO ENTERPRISE IN KAMPAR DISTRICT, RIAU PROVINCE}

\author{
Samsurijal Hasan \\ Universitas Pahlawan Tuanku Tambusai \\ samsurijal.sfmc@gmail.com
}

\begin{abstract}
Small and Medium Enterprises is one of the priority programs from Indonesia government is to improve the regional and national economy. Since this industry become the backbone of a populist economic system that is not only intended to reduce the problem of inequality between income groups and between businesses, or alleviating poverty and employment. Unfortunately, Business competition is tight at this time is a challenge for businesses to remain in the global competition. Entrepreneurs who cannot meet consumer tastes will increasingly be left behind and businesses will not develop. Determining the effect of Promotion Mix on the Marketing Performance of Micro, Small and Medium Enterprises in Kampar District is the main objective of this study. The independent variable in this study is the promotion mix and the dependent variable is marketing performance. The analytical model used is a simple linear regression analysis. The number of samples in this study was 96 respondents. The sampling technique uses accidental sampling. Based on the results of the study it can be concluded that there is a significant effect of the promotion mix variable on the Marketing Performance of Micro, Small and Medium Enterprises in Kampar District. Promotional mix variables and marketing performance have a strong relationship with the promotion mix contribution to marketing performance are also quite high at $67.60 \%$ determined by promotional mix variables, while the remaining $32.40 \%$ is determined by other factors outside the model. It is recommended to MSME entrepreneurs in Kampar Regency, to increase product promotion so that MSME entrepreneurs maintain personal sales because they are most sought after by consumers, so that by increasing personal sales, it will improve the marketing performance of MSME entrepreneurs in Kampar Regency.
\end{abstract}

Keywords: Promotion Mix, Marketing Performance, Small and Medium Micro Enterprise, Kampar

\begin{abstract}
ABSTRAK
Usaha Kecil dan Menengah adalah salah satu program prioritas pemerintah Indonesia untuk meningkatkan perekonomian regional dan nasional. Karena industri ini menjadi tulang punggung sistem ekonomi kerakyatan yang tidak hanya dimaksudkan untuk mengurangi masalah ketidaksetaraan antara kelompok pendapatan dan antara bisnis, atau mengurangi kemiskinan dan pekerjaan. Sayangnya, persaingan bisnis yang ketat saat ini merupakan tantangan bagi bisnis untuk tetap berada dalam persaingan global.
\end{abstract}


Pengusaha yang tidak bisa memenuhi selera konsumen akan semakin tertinggal dan bisnis tidak akan berkembang. Menentukan pengaruh Bauran Promosi terhadap Kinerja Pemasaran Usaha Mikro, Kecil dan Menengah di Kabupaten Kampar adalah tujuan utama dari penelitian ini. Variabel independen dalam penelitian ini adalah bauran promosi dan variabel dependen adalah kinerja pemasaran. Model analisis yang digunakan adalah analisis regresi linier sederhana. Jumlah sampel dalam penelitian ini adalah 96 responden. Teknik pengambilan sampel menggunakan accidental sampling. Berdasarkan hasil penelitian dapat disimpulkan bahwa ada pengaruh yang signifikan dari variabel bauran promosi terhadap Kinerja Pemasaran Usaha Mikro, Kecil dan Menengah di Kabupaten Kampar. Variabel bauran promosi dan kinerja pemasaran memiliki hubungan yang kuat dengan kontribusi bauran promosi terhadap kinerja pemasaran juga cukup tinggi yaitu $67,60 \%$ ditentukan oleh variabel bauran promosi, sedangkan sisanya 32,40\% ditentukan oleh faktor lain di luar model. Direkomendasikan kepada para pengusaha UMKM di Kabupaten Kampar, untuk meningkatkan promosi produk sehingga para pengusaha UMKM menjaga penjualan pribadi karena mereka paling dicari oleh konsumen, sehingga dengan meningkatkan penjualan pribadi, itu akan meningkatkan kinerja pemasaran para pengusaha UMKM di Kabupaten Kampar

Keywords: Bauran Promosi, Kinerja Pemasaran, Usaha Mikro Kecil dan Menengah, Kampar

\section{PENDAHULUAN}

Persaingan bisnis yang ketat pada saat ini merupakan sebuah tantangan bagi pengusaha untuk tetap berada dalam persaingan global. Pengusaha yang tidak dapat memenuhi selera konsumen akan semakin tertinggal dan usaha tidak akan berkembang. Keadaan usaha bersifat dinamis yang selalu mengalami perubahan cara pelaksanaan kegiatan pemasaran yang berbeda-beda. Pemasaran yang dilakukan adalah dengan melaksanakan bauran promosi yang nantinya akan berdampak pada kinerja pemasaran (Hasan, 2020).

$$
\text { Kinerja pemasaran ini }
$$
merupakan konsep untuk mengukur prestasi pasar dari produk, seperti tingginya volume penjualan, tingginya market share, serta tingginya profitabilitas pemasaran, yang digunakan sebagai cermin dari keberhasilan usahanya di kancah persaingan dunia usaha. Sulitnya pedagang memahami orientasi pasar, selain itu, kelengkapan produk juga menjadi hambatan pedagang dalam menaikkan kinerja pemasaran mereka, kurangnya efektifitas saluran distribusi juga menjadi faktor penghambat kinerja pemasaran para pedagang, sehingga pemerintah perlu memberikan semacam pendidikan dan pelatihan bagi pedagang yang termasuk ke dalam UMKM tersebut (Hasan, 2019).

Promosi merupakan salah satu cakupan bauran pemasaran yang penting dalam memasarkan barang atau jasa yang dihasilkan perusahaan dan juga sebagai suatu cara memberikan informasi kepada masyarakat tentang barang atau jasa yang dihasilkan sebuah perusahaan. Promosi juga berarti aktivitas yang mengkomunikasikan keunggulan produk dan membujuk sasaran untuk membelinya. Oleh karena itu, perusahaan selalu membangun komunikasi sebaik mungkin kepada konsumennya dan calon konsumennya melalui promosi. Promosi berhubungan erat dengan komunikasi. Ketika perusahaan mengembangkan produk baru, mengubah yang lama atau bahkan 
mencoba meningkatkan penjualan atas barang dan jasa yang ada, perusahaan harus menginformasikan pesan penjualannya kepada calon konsumen. Para pemasar mengkomunikasikan informasi tentang perusahaan dan produk-produknya melalui program promosinya (Kotler, 2011; Stanton, 2012).

Usaha Mikro Kecil dan Menengah (UMKM) mengalami perbedaan yang terlihat di setiap kecamatan, hal ini disebabkan oleh semakin ketatnya persaingan di antara pelaku bisnis, maka masing-masing harus bisa menentukan strategi terbaik untuk memenangkan persaingan, serta mampu mempertahankan market share yang telah diraih agar tidak direbut pesaing. Selain itu, pada kenyataannya kondisi di lapangan tidak seperti harapan, beberapa UMKM ada yang berangsur-angsur mengalami penurunan dari segi kualitas produk maupun jumlah usahanya. Kenyataan ini berbanding terbalik dengan program pemerintah yang berusaha mengangkat UMKM agar terus berkembang agar terus menyokong ekonomi Negara (Rully, 2019, Sulaiman, 2018).

Permasalahan berikutnya adalah bauran promosi yang semakin berkurang dilakukan oleh pelaku UMKM. Minimnya orientasi pasar untuk mengenalkan dan memahami keinginan konsumen, melihat pesaing baik dari dalam ataupun luar negeri, peraturan yang diberlakukan oleh pemerintah dan target yang harus dituju membuat pelaku UMKM semakin menurun. Kurangnya pemahaman akan pemuasan konsumen di waktu sekarang ataupun akan datang. Sulitnya daya saing dalam hal bauran promosi produk yang membuat minat masyarakat akan produk mereka menurun.

Permasalahan

tersebut

berdampak pada kinerja pemasaran yang dijalankan. Sebab kinerja pemasaran yang baik mampu membuat perusahaan dalam hal ini UMKM bertahan dalam kondisi pasar yang bergerak cepat. Sehingga untuk bias mempertahankan kinerja pemasaran dipersaingan yang ketat tersebut diperlukan usaha berupa promosi yang baik dan tepat sasaran, berani mengambil resiko dan agresif. Bauran promosi yang dapat bersaing menjadi pendukung akhir dalam kinerja pemasaran dimana untuk meningkatkan kompetensi agar lebih kompeten dalam menjalankan usaha (Kementerian Perindustrian Republik Indonesia, 2019).

Pentingnya kinerja pemasaran diantaranya konsep pemasaran dan orientasi pasar sebagai implementasinya telah menciptakan superior value, maka gambaran yang jelas tentang bauran promosi yang mendukung dan menghalangi pengembangan kinerja pemasaran sangat dibutuhkan untuk menjelaskan bagaimana sebuah perusahaan bisa lebih berorientasi pasar dibanding perusahaan lain (Wahyuningsih, 2018).

Fenomena yang terjadi di lapangan yang berhubungan dengan bauran promosi yakni masih kurangnya iklan promosi dari usaha kecil dan menengah yang ada di Kabupaten Kampar. Hubungan masyarakat antara pengusaha UMKM dengan konsumen juga masih belum optimal, pemasaran langsung yang belum terlaksana dengan baik serta minimnya promosi penjualan perseorangan yang dilakukan oleh pengusaha UMKM yang ada di Kabupaten Kampar (Hasan, 2020, Dinas Koperasi, Riau, 2018).

Pemasaran muncul dari cara terakhir orang untuk mendapatkan suatu produk, yaitu dengan cara pertukaran. Pertukaran adalah cara untuk mendapatkan suatu produk yang diinginkan dari seseorang dengan 
menawarkan suatu sebagai gantinya. Pemasaran juga berarti keinginan manusia yang berlangsung dalam kaitan dengan pasar, juga berarti bekerja dengan pasar untuk mewujudkan pertukaran yang potensial dengan maksud memuskan kebutuhan dan keinginan manusia. Berikut beberapa pendapat tentang pemasaran dari para ahli Pemasaran adalah kegiatan yang bertujuan memperlancar arus barang dan jasa dari produsen secara efisien dengan maksud menciptkan permintaan yang efektif. Pemasaran adalah kegiatan meneliti kebutuhan dan keinginan konsumen, menghasilkan barang atau jasa, menentukan harga, mempromosikan serta mendistribusikan barang dan jasa (Safina 2011).

Bauran komunikasi juga dikenal dengan istilah promotion mix. Bauran promosi ini digunakan untuk membangun merek dan membangun kesetiaan pelanggan. Bauran promosi adalah aktifitas yang digunakan manusia untuk mengkomunikasikan kepada orang lain tentang produk atau jasa yang mereka tawarkan, dan meyakinkan orang lain tersebut untuk menggunakannya. Metode komunikasi terdiri atas impersonal komunikasi berbayar, personal komunikasi berbayar, impersonal komunikasi tidak berbayar, impersonal komunikasi berbayar terdiri atas periklanan, Promosi, Diskon, Hadiah, Tenaga Promosi, atmosfir toko, web-site, dan membangun komunitas.

Bauran promosi pemasaran adalah berbagai macam model sarana dimana perusahaan berusaha menginformasikan, membujuk dan mengingatkan konsumen secara langsung maupun tidak langsung tentang produk dan merek yang dijual. Terdapat dua faktor yang mempengaruhi kinerja UMKM di Kabupaten Bangli, yaitu: (1) faktor internal, dan (2) faktor eksternal. Faktor yang paling dominan mempengaruhi kinerja UMKM di Kabupaten Bangli adalah faktor internal, yang meliputi: pemasaran, akses permodalan, kemampuan berwirausaha, SDM, pengetahuan keuangan dan rencana bisnis.

\section{METODE PENELITIAN}

Penelitian ini dilakukan pada UMKM Kabupaten Kampar dengan durasi penelitian dilaksanakan selama 2 (Dua) bulan. Dua sumber data digunakan yakni Data Primer, adalah data yang diperoleh langsung dari tanggapan responden yang berhubungan dengan objek penelitian, yaitu konsumen melalui kuesioner. Disamping itu, data Sekunder, adalah data yang diperoleh dari perusahaan seperti sejarah UMKM Kabupaten Kampar, kondisi geografis serta keadaan penduduk Kabupaten Kampar.

Data yang didapat dari penelitian bersifat kualitatif, maka data yang bersifat kualitatif itu diberikan skala sehingga menjadi data yang bersifat kuantitatif. Skala yang digunakan adalah skala ordinal, yaitu data yang diperoleh dengan cara kategorisasi atau klasifikasi, tetapi diantara data tersebut terdapat hubungan. Dengan Skala ordinal, maka variabel yang akan diukur dijabarkan menjadi indikator variabel. dimana setiap pertanyaan akan diberikan skor numerik berkisar antara 1-5. Alur kerja penilitan dapat dilihat pada gambar 1 . 


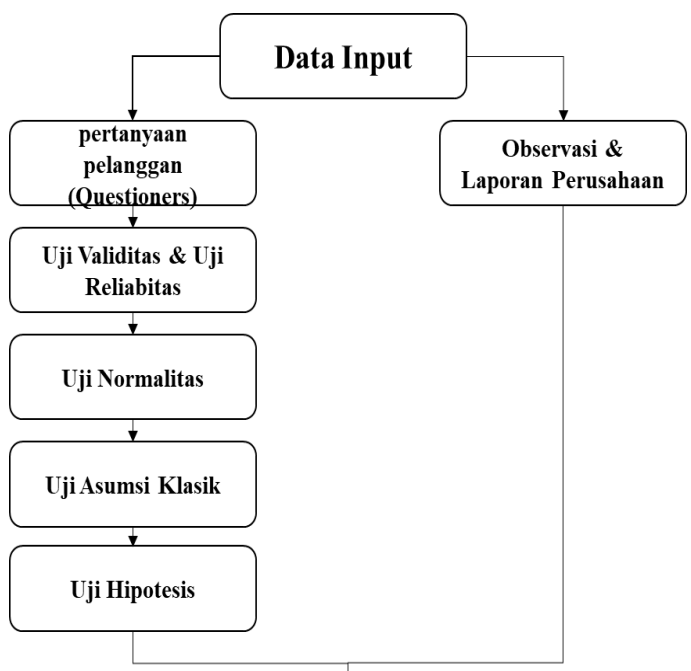

KONSEKUENSI PENERAPAN MIX PROMOSI TERHADAP KINERJA PEMASARAN BISNIS MIKRO KECIL DAN MENENGAH DI KABUPATEN KAMPAR, PROVINSI RIAU

Gambar 1. Alur kerja peniltian.

\section{HASIL DAN PEMBAHASAN Identitas Responden}

Data primer yang diperoleh langsung dari responden dengan menggunakan kuesioner. Responden dalam penelitian ini adalah pengusaha UMKM yang berjumlah 96 orang. Sebanyak 62 orang atau $65,58 \%$ responden merupakan berjenis kelamin pria dan sebanyak 34 orang atau $35,42 \%$ responden merupakan pengusaha wanita. Nilai ini menunjukkan bahwa pada UMKM di Kabupaten Kampar memiliki pengusaha pria lebih banyak jumlahnya. Pada prinsipnya. Sedangkan jika dilihat dari umur, bahwa sebanyak 23 Orang atau $23,96 \%$ responden berumur kurang dari 30 Tahun, sebanyak 51 Orang atau $53,13 \%$ responden berumur 30-40 Tahun dan sebanyak 22 Orang atau $22,92 \%$ responden berumur di atas 40 Tahun. Nilai ini menunjukkan bahwa pada UMKM di Kabupaten Kampar memiliki responden berumur antara 3040 Tahun lebih banyak. Hal ini menunjukan bahwa sebagian besar pengusaha UMKM di Kabupaten Kampar banyak yang berada pada usia produktif.

\section{Hasil Analisis Deskriptif}

Dari tanggapan responden tertinggi sebesar 4,18 dengan kategori Setuju untuk indikator yakni pengusaha UMKM merasa penjualan personal terhadap produk UMKM sudah menarik perhatian konsumen. Hal ini menjelaskan bahwa secara umum bahwa pengusaha UMKM dapat mempromosikan produknya dengan penjualan personal sehingga sebaiknya perusahaan dapat mempertahankan penjualan personal tersebut.

Sedangkan pernyataan terendah sebesar 2,93 dengan kategori Cukup Setuju untuk pernyataan yakni Pengusaha merasa pemasaran langsung produk UMKM sudah menarik perhatian konsumen. Hal ini memperlihatkan bahwa pengusaha UMKM belum memenuhi dapat menarik perhatian konsumen dengan promosi pemasaran langsung dengan konsumen, sehingga sebaiknya dapat memperbaki dan meningkatkan $\mathrm{lg}$ pemasaran langsung dengan konsumen, sehingga dapat meningkatkan kinerja pemasaran.

Secara keseluruhan tanggapan responden untuk semua pernyataan untuk indikator variabel bauran promosi diperoleh skor rata-rata sebesar 3,58 dengan nilai skor maksimal sebesar 5,00. jika hasil ini disajikan dalam garis interval, maka diperoleh hasil sebagai berikut:

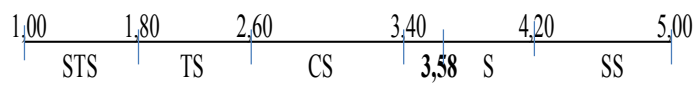

Dari interval diatas terlihat bahwa tanggapan responden berada pada rentang dengan kategori Setuju. Hasil ini menjelaskan bahwa indikator bauran promosi sudah dirasa baik oleh pengusaha UMKM. Tentu hal ini perlu ditingkatkan lagi oleh pihak pengusaha UMKM. 
Dari tanggapan responden tertinggi sebesar 4,06 dengan kategori Setuju untuk pernyataan Kinerja pemasaran akan menjadi lebih baik apabila volume penjualan meningkat. Hal ini menjelaskan bahwa secara umum bahwa kinerja pemasaran pengusaha UMKM meningkat apabila volume penjualan juga meningkat, sehingga pihak pengusaha UMKM sebaiknya dapat mempertahankan kinerja pemasaran yang baik tersebut.

Sedangkan pernyataan terendah sebesar 3,02 dengan kategori Cukup Setuju untuk pernyataan yakni Orientasi Pesaing dibutuhkan agar memudahkan pengusaha UMKM dalam memahami kekuatan dan kelemahan pesaing. Hal ini memperlihatkan bahwa pengusaha UMKM belum sepenuhnya mengetahui kelemahan dan kekuatan pesaing, sehingga pihak manajemen sebaiknya dapat memperbaiki dan memperhatikan tentang kelemahan dan kekuatan pesaing sehingga kinerja pemasaran dapat meningkat.

Secara keseluruhan tanggapan responden untuk semua pernyataan untuk indikator variabel kinerja pemasaran diperoleh skor rata-rata sebesar 3,64 dengan nilai skor maksimal sebesar 5,00. jika hasil ini disajikan dalam garis interval, maka diperoleh hasil sebagai berikut:

\begin{tabular}{lllllllll}
1,00 & 1,80 & 2,60 & & 3,40 & & 4,20 & & 5,00 \\
\hline STS & TS & & CS & & 3,58 & $S$ & & SS
\end{tabular}

Dari interval diatas terlihat bahwa tanggapan responden berada pada rentang dengan kategori Setuju. Hasil ini menjelaskan bahwa indikator kinerja pemasaran sudah dirasa baik oleh pengusaha UMKM. Tentu hal ini perlu ditingkatkan lagi oleh pihak pengusaha UMKM.

\section{Hasil Analisis Deskriptif}

Uji validitas bertujuan untuk mengetahui item-item atau pernyataan yang valid dalam menentukan sebuah variabel. Pengujian dilakukan dengan membandingkan nilai koefisien korelasi (r) antara item pernyataan dengan skor totalnya dengan cara membandingkan $r$ hitung dengan $r$ tabel. Berikut ini hasil pengujian validitas, dapat dilihat pada Tabel 1

Tabel 1 Hasil Pengujian Validitas

\begin{tabular}{|c|c|c|c|c|}
\hline Variabel & Item & $\begin{array}{c}\mathbf{r} \\
\text { Hitung }\end{array}$ & $\begin{array}{c}\mathbf{r} \\
\text { Tabel }\end{array}$ & Keterangan \\
\hline \multirow{12}{*}{ 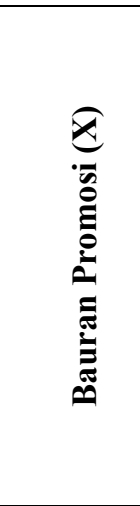 } & 1 & 0,540 & 0,201 & Valid \\
\hline & 2 & 0,370 & 0,201 & Valid \\
\hline & 3 & 0,254 & 0,201 & Valid \\
\hline & 4 & 0,556 & 0,201 & Valid \\
\hline & 5 & 0,631 & 0,201 & Valid \\
\hline & 6 & 0,467 & 0,201 & Valid \\
\hline & 7 & 0,587 & 0,201 & Valid \\
\hline & 8 & 0,416 & 0,201 & Valid \\
\hline & 9 & 0,503 & 0,201 & Valid \\
\hline & 10 & 0,335 & 0,201 & Valid \\
\hline & 11 & 0,753 & 0,201 & Valid \\
\hline & 12 & 0,312 & 0,201 & Valid \\
\hline \multirow{12}{*}{ 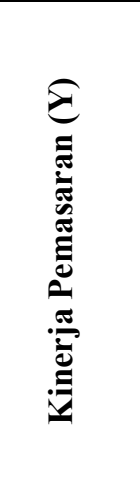 } & 1 & 0,566 & 0,201 & Valid \\
\hline & 2 & 0,255 & 0,201 & Valid \\
\hline & 3 & 0,396 & 0,201 & Valid \\
\hline & 4 & 0,452 & 0,201 & Valid \\
\hline & 5 & 0,607 & 0,201 & Valid \\
\hline & 6 & 0,338 & 0,201 & Valid \\
\hline & 7 & 0,505 & 0,201 & Valid \\
\hline & 8 & 0,512 & 0,201 & Valid \\
\hline & 9 & 0,429 & 0,201 & Valid \\
\hline & 10 & 0,434 & 0,201 & Valid \\
\hline & 11 & 0,610 & 0,201 & Valid \\
\hline & 12 & 0,430 & 0,201 & Valid \\
\hline
\end{tabular}

Sumber : Hasil Olahan Data, 2020

Variabel bauran promosi terdiri dari 12 (Dua Belas) butir pernyataan yang merupakan penjabaran dari beberapa indikator yang menentukan variabel bauran promosi. Begitu juga dengan variabel kinerja pemasaran yang terdiri dari 12 (Dua Belas) butir pernyataan. Dari Tabel 1 tersebut terlihat bahwa indikator variabel buaran 
promosi dan kinerja pemasaran dari hasil uji validitas, maka dapat dikatakan bahwa semua pernyataan dinyatakan valid, karena koefisien korelasi dari semua butir pernyataan lebih besar dari nilai $r$ tabelnya. Dimana variabel pernyataan dan semuanya juga dinyatakan valid.

\section{Hasil Hasil Uji Reliabilitas}

Selanjutnya semua butir pertanyaan yang valid dari masingmasing variabel tersebut dilakukan uji reliabilitas. Pengujian ini bertujuan untuk mengetahui tingkat kehandalan dari butir-butir pertanyaan yang valid dalam menentukan nilai varaibel yang bersangkutan. Hasil pengolahan data diketahui hasil pengujian reliabilitas seperti Tabel 2

Tabel 2 Hasil Uji Reliability

\begin{tabular}{lcc}
\hline Variabel & $\begin{array}{c}\text { Alpha } \\
\text { Cronbach } \boldsymbol{S}\end{array}$ & Keterangan \\
\hline (X) & 0,803 & Reliabel/Handal \\
(Y) & 0,805 & Reliabel/Handal
\end{tabular}

\section{Sumber : Hasil Pengolahan Data, 2020}

Berdasrakan hasil pengujian, dimana reliabilitas untuk variabel bauran promosi dan kinerja pemasaran diperoleh nilai alpha cronbach 's diatas 0,5 , ini berarti bahwa tingkat kehandalan dari butir-butir pertanyaan untuk variabel yang diteliti sudah baik.

\section{Hasil Uji Normalitas Data}

Pengujian ini bertujuan untuk melihat apakah data yang digunakan mengikuti pola distribusi normal atau tidak. Karena model yang baik data harus mengikuti pola distribusi normal. Hasil pengujian dengan P-P Plot of Regression Standardized Residual, adalah sebagai berikut (Gambar 2).

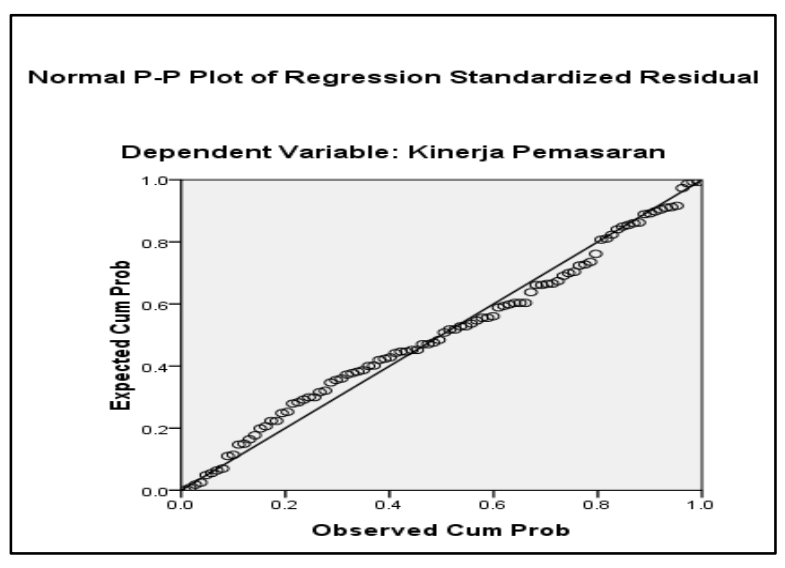

\section{Gambar 2 Kurva Hasil Uji Normalitas}

Dari kurva diatas terlihat bahwa data menyebar disepanjang garis lurus, dengan demikian berarti bahwa dari data atau nilai residual sudah mengikuti distribusi normal.

\section{Hasil Hasil Uji Uji Hipotesis}

Pengujian hipotesis pada penelitian ini dilakukan dengan uji $t$ yang diperoleh dari regersi linear sederhana, dan hasil pengolahan data diperoleh hasil dandapat dibuat persamaan regresi linear sederhana sebagai berikut:

$$
Y=11,356+0,736 X
$$

Arti angka-angka pada persamaan diatas adalah sebagai berikut: Nilai konstanta (a) adalah bernilai positif 11,356 artinya jika bauran promosi bernilai 0 (nol), maka kinerja pemasaran tetap ada sebesar 11,356 satuan. Nilai koefisien regresi variabel bauran promosi (b) bernilai positif, yaitu 0,736 ; artinya setiap peningkatan variabel bauran promosi sebesar 1 satuan meningkatkan kinerja pemasaran sebesar 0,736 satuan dengan asumsi variabel lain bernilai nol. 
Tabel 3 Hasil Analisis Regresi Linear Sederhana Coefficients ${ }^{\mathrm{a}}$

\begin{tabular}{|c|c|c|c|c|c|c|c|c|}
\hline \multirow{2}{*}{\multicolumn{2}{|c|}{ Model }} & \multicolumn{2}{|c|}{ Unstandardized Coefficients } & \multirow{2}{*}{$\begin{array}{c}\begin{array}{c}\text { Standardized } \\
\text { Coefficients }\end{array} \\
\text { Beta } \\
\end{array}$} & \multirow[b]{2}{*}{$\mathrm{t}$} & \multirow[b]{2}{*}{ Sig. } & \multicolumn{2}{|c|}{$\begin{array}{c}\text { Collinearity } \\
\text { Statistics }\end{array}$} \\
\hline & & $\mathrm{B}$ & Std. Error & & & & Tolerance & VIF \\
\hline \multirow[t]{2}{*}{$\overline{1}$} & (Constant) & 11.356 & 2.803 & & 4.051 & .000 & & \\
\hline & Bauran Promosi & .736 & .065 & .759 & 11.291 & .000 & 1.000 & 1.000 \\
\hline
\end{tabular}

a. Dependent Variable: Kinerja Pemasaran

Sumber : Hasil Pengolahan Data, 2020

Tabel 4. Koefisien Korelasi (R) dan Koefisien Determinasi $\left(\mathbf{R}^{\mathbf{2}}\right)$

Model Summary ${ }^{\mathrm{b}}$

\begin{tabular}{llrrrr}
\hline Model & R & R Square & & & \\
& & & Adjusted R Square & Std. Error of the Estimate & Durbin-Watson \\
\hline 1 & $.759^{\mathrm{a}}$ & .676 & .671 & 4.426 & 2.079 \\
\hline
\end{tabular}

a. Predictors: (Constant), Bauran Promosi

b. Dependent Variable: Kinerja Pemasaran

\section{Hasil Uji Hipotesis (Uji t)}

Berdasarkan hasil analisis ditemukan bahwa terdapat signifikansi dari variabel bauran promosi (X) sebesar 0,000. Berdasarkan signifikansi didapat bahwa signifikansi variabel bauran promosi lebih kecil dari 0,05 $(0,000<0,05)$. Maka terdapat pengaruh yang signifikan dari variabel bauran promosi terhadap kinerja pemasaran, semakin meningkat nilai variabel bauran promosi maka nilai variabel kinerja pemasaran juga akan meningkat dengan $\mathrm{t}$ hitung sebesar 11,291 dan alpha (a) 0,05.

\section{Hasil Uji Koefisien Korelasi (R) dan Determinasi $\left(\mathbf{R}^{2}\right)$}

Dari hasil uji koefisen korelasi maka ditemukan bahwa Koefisien Korelasi (R) diperoleh sebesar 0,759 yang terletak antara 0,700-0,799 pada Tabel Interprestasi Koefisien Korelasi, hal ini memberi arti bahwa antara variabel bauran promosi terdapat keeratan hubungan yang erat/kuat terhadap kinerja pemasaran .

Sedangkan Untuk melihat kontribusi variabel bauran promosi terhadap kinerja pemasaran, dapat digunakan koefisien determinasi (R2). Dari hasil pengolahan data diperoleh koefisien sebesar 0,676, ini memberikan arti bahwa variasi kinerja pemasaran sebesar $67,60 \%$ ditentukan oleh variabel bauran promosi, sedangkan sisanya $32,40 \%$ lagi ditentukan oleh faktor lain diluar model (Tabel 4).

Dari hasil penelitian di peroleh bahwa variabel bauran promosi berpengaruh terhadap Kinerja Pemasaran Usaha Mikro Kecil dan Menengah Di Kabupaten Kampar. Menilai bauran promosi digunakan beberapa indikator. Hal ini menunjukkan tanggapan responden terhadap pernyataan variabel bauran promosi. Dari tanggapan responden tertinggi sebesar 4,18 dengan kategori Setuju untuk indikator yakni pengusaha UMKM merasa penjualan personal 
terhadap produk UMKM sudah menarik perhatian konsumen. Hal ini menjelaskan bahwa secara umum bahwa pengusaha UMKM dapat mempromosikan produknya dengan penjualan personal sehingga sebaiknya perusahaan dapat mempertahankan penjualan personal tersebut.

Sedangkan pernyataan terendah sebesar 2,93 dengan kategori Cukup Setuju untuk pernyataan yakni Pengusaha merasa pemasaran langsung produk UMKM sudah menarik perhatian konsumen. Hal ini memperlihatkan bahwa pengusaha UMKM belum memenuhi dapat menarik perhatian konsumen dengan promosi pemasaran langsung dengan konsumen, sehingga sebaiknya dapat memperbaki dan meningkatkan $\mathrm{lg}$ pemasaran langsung dengan konsumen, sehingga dapat meningkatkan kinerja pemasaran.

Secara keseluruhan tanggapan responden untuk semua pernyataan untuk indikator variabel bauran promosi diperoleh skor rata-rata sebesar 3,58 dengan nilai skor maksimal sebesar 5,00. jika hasil ini disajikan dalam garis interval, maka diperoleh bahwa tanggapan responden berada pada rentang dengan kategori Baik. Hasil ini menjelaskan bahwa indikator bauran promosi sudah dirasa baik oleh pengusaha UMKM. Tentu hal ini perlu ditingkatkan lagi oleh pihak pengusaha UMKM.

Untuk memperkuat hasil penelitian ini, disini peneliti mengemukakan hasil penelitian Maharani (2014) bauran promosi pemasaran adalah berbagai macam model sarana dimana perusahaan berusaha menginformasikan, membujuk dan mengingatkan konsumen secara langsung maupun tidak langsung tentang produk dan merek yang dijual. Bauran promosi pemasaran juga melaksanakan banyak fungsi bagi konsumen. promosi pemasaran dapat memberitahu atau memperlihatkan kepada konsumen tentang bagaimana dan mengapa produk itu digunakan, oleh orang macam apa, serta dimana dan kapan.

Bauran promosi (promotion mix), juga disebut bauran komunikasi pemasaran (marketing communication mix) perusahaan merupakan paduan spesifik iklan, promosi penjualan, hubungan masyarakat/publikasi, penjualan personal, dan sarana pemasaran langsung yang digunakan perusahaan untuk mengkomunikasikan nilai pelanggan secara persuasif dan membangun hubungan pelanggan (Wardani, 2014).

Sedangkan menurut George dan Michael Belch, tidak berbeda jauh yaitu Iklan, Internet, Pemasaran Langsung, Promosi Penjualan, Publikasi / Humas, dan Penjualan Personal. Namun teori Bauran Komunikasi Pemasaran ini merupakan breakdown dari teori Komunikasi Pemasaran. Marketing communications (Komunikasi Pemasaran) merupakan salah satu organ vital dalam perusahaan. Hal ini disebabkan oleh peranan komunikasi yang tidak hanya pendukung transaksi dengan menginformasikan, membujuk, mengingat dan membedakan produk, tetapi juga menawarkan sarana pertukaran itu sendiri (Wardani, 2014).

Alat komunikasi pemasaran dalam industri pariwisata, yaitu periklanan, pemasaran langsung, promosi penjualan, dan pameran perdagangan. Menurut, internet, sponsorship dan point of purchase juga termasuk dalam alat komunikasi pemasaran tersebut. Dua unsur terakhir, yaitu direct marketing dan interactive media telah digunakan secara luas oleh pengelola pemasaran dewasa ini untuk dapat berkomunikasi dengan khalayak 
sasarannya, sebagaimana empat unsur sebelumnya.

Bauran promosi (promotion mix), juga disebut bauran komunikasi pemasaran (marketing communication mix) perusahaan merupakan paduan spesifik iklan, promosi penjualan, hubungan masyarakat/publikasi, penjualan personal, dan sarana pemasaran langsung yang digunakan perusahaan untuk mengkomunikasikan nilai pelanggan secara persuasif dan membangun hubungan pelanggan (Wardani, 2014, Hasan 2020). Sedangkan menurut George dan Michael Belch, tidak berbeda jauh yaitu Iklan, Internet, Pemasaran Langsung, Promosi Penjualan, Publikasi / Humas, dan Penjualan Personal. Namun teori Bauran Komunikasi Pemasaran ini merupakan breakdown dari teori Komunikasi Pemasaran. Marketing communications (Komunikasi Pemasaran) merupakan salah satu organ vital dalam perusahaan. Hal ini disebabkan oleh peranan komunikasi yang tidak hanya pendukung transaksi dengan menginformasikan, membujuk, mengingat dan membedakan produk, tetapi juga menawarkan sarana pertukaran itu sendiri.

Komunikasi pemasaran adalah proses penyampaian dan perpaduan stimuli kepada target pasar yang bertujuan untuk menimbulkan respon dan minat akan produk serta membangun saluran untuk menerima, menginterpretasikan dan melakukan tindakan terhadap pesan dari pasar dengan maksud menyesuaikan ide perusahaan saat ini dan mengidentifikasi peluang baru dalam berkomunikasi. Komunikasi pemasaran perlu diterapkan mulai dari tataran bauran pemasaran (marketing mix), yaitu pemasaran memfasilitasi proses pertukaran dan perkembangan hubungan dengan konsumen dengan cara mengamati secara cermat kebutuhan dan keinginan konsumen yang dilanjutkan dengan mengembangkan suatu produk (product) yang memuaskan kebutuhan konsumen dan menawarkan produk pada harga (price) tertentu serta mendistribusikannya agar tersedia di tempat-tempat (place) yang menjadi pasar bagi produk bersangkutan. Untuk itu perlu dilaksanakan suatu program promosi (promotion) atau komunikasi guna menciptakan kesadaran dan ketertarikan konsumen kepada produk bersangkutan. Proses ini disebut dengan marketing mix / bauran pemasaran yang terdiri atas elemen-elemen, yaitu product, price, place(distribution) dan promotion yang disingkat dengan "Empat P" (Wardani, 2014).

Program pemasaran yang efektif adalah dari penggabungan berbagai elemen dari marketing mix ke dalam strategi pemasaran yang bulat dan utuh (kohesif). Pengelola pemasaran hingga kini masih ada yang beranggapan bahwa kegiatan promosi yang paling efektif adalah beriklan melalui media massa. Perusahaan bergantung pada biro iklan dalam memberikan bimbingan dan saran kepada manajemen mengenai hampir segala hal yang terkait dengan komunikasi pemasaran. Bentuk-bentuk komunikasi pemasaran lain, selain beriklan di media massa, seperti promosi penjualan atau pemasaran langsung masih dianggap sebagai pekerjaan tambahan dan lebih sering digunakan untuk mengelola kegiatan publisitas,mengelola citra serta menangani urusan dengan publik (Wardani, 2014, Wahyuningsih, 2018).

\section{PENUTUP \\ Kesimpulan}

Berdasarkan hasil penelitian dapat disimpulan dan ditemukan bahwa: 
1. Variabel bauran promosi berpengaruh signifikan terhadap terhadap Kinerja Pemasaran Usaha Mikro Kecil dan Menengah Di Kabupaten Kampar, dengan indikator rata-rata tertinggi yaitu penjualan personal sebesar 4,18 dengan kategori Setuju, dan indikator ratarata terendah adalah pemasaran langsung sebesar 2,93 dengan kategori Cukup Setuju.

2. Keeratan hubungan variabel bauran promosi terhadap variabel kinerja pemasaran adalah kuat/ erat, sedangkan besarnya kontribusi antara variabel bauran promosi dengan variabel kinerja pemasaran sebesar 0,676, ini memberikan arti bahwa variasi kinerja pemasaran sebesar $67,60 \%$ ditentukan oleh variabel bauran promosi, sedangkan sisanya $32,40 \%$ lagi ditentukan oleh faktor lain diluar model.

\section{Saran}

1. Pengusaha UMKM di Kabupaten Kampar, untuk meningkatkan promosi produk agar pengusaha UMKM mempertahankan penjualan personal dikarenakan paling diminati konsumen, sehingga dengan meningkatnya penjualan personal akan meningkatkan kinerja pemasaran pengusaha UMKM yang ada di Kabupaten Kampar.

2. Pengusaha UMKM di Kabupaten Kampar agar memperhatikan dan lebih memberikan promosi produk melalui pemasaran langsung atau bertatap muka dengan pelanggan, sehingga dengan demikian diharapkan dapat meningkatkan kinerja pemasaran.

\section{DAFTAR PUSTAKA}

Dinas Koperasi dan UKM Provinsi Riau. (2018). Rencana Strategis Dinas Koperasi dan UKM Provinsi Riau 2014 - 2017. Pemerintah Provinsi Riau. Pekanbaru

Hasan, S. (2020). Kunci Sukses Kepuasan Pelanggan: Upaya Membangun BUMD. Edisi 1. Serang: Media Madani

Hasan, S. (2020). Strategi Membangun Citra BUMD. Edisi 1. Serang: Media Madani

Hasan, S. (2020). Citation: The Influence Of Service Quality, Distribution Performance And Customer Orientation To Customer Satisfaction And Its Impact On Corporate Image (Study On Water Supply Company Tirta Siak In Riau Province). Jardacs Special Issues. 11 (8).1258-1270

Kementerian Perindustrian Republik Indonesia. (2019). Making Indonesia 4.0: Strategi RI Masuki Revolusi Industri Ke-4. Retrieved from kemenperin.go.id:

http://www.kemenperin.go.id /artikel/18967/ MakingIndonesia-4.0:-Strategi-RIMasuki-Revolusi-Industri-Ke-4

Kotler, Philip \& Armstrong, G. (2012). Prinsip-Prinsip Pemasaran. Edisi 13. Jilid 1. Jakarta: Erlangga

Maharani, Kurnia \& Isnowati, S. (2014). "Kajian Investasi, Pengeluaran Pemerintah, Tenaga Kerja dan Keterbukaan Ekonomi Terhadap Pertumbuhan Ekonomi di Provinsi Jawa Tengah". Jurnal Bisnis dan Ekonomi. 21(1):62-72. 
Rully, I. (2019). Sinergitas enegmbangan KUMKM melalui Penguatan Peran Antar Lembaga. Rapat Kerja Nasional. Bali

Safina, L., \& Rahayu, S.,E. (2011). Analisis Pengaruh Investasi Pemerintah dan Swasta Terhadap Penciptaan Kesempatan Kerja di Sumatera Utara. Jurnal Manajemen \& Bisnis. 11(1).

Sri, W. (2018). Peranan UKM Dalam Era Digital. Jurnal Ilmu ilmu Pertanian

Stanton, W., J. (2012). Prinsip Pemasaran, Alih Bahasa : Yohanes Lamarto Penerbit Erlangga,

Sulaiman. (2018). Fintech: Peluang dan Tantangan di Era Digital Ekonomi. Doctorate Business Issue Forum (Dorbis).

Wardani, V. (2014). The Effectof Fundamental Factor to Dividend Policy: Evidence in Indonesia Stock Exchange. International Journal of Business and Commerce, 4(8), 14-25. 